LPPM UNIHAZ $\quad \begin{array}{lll}\text { ABDIHAZ: Jurnal Ilmiah Pengabdian pada Masyarakat } \\ \text { https://journals.unihaz.ac.id/index.php/abdihaz }\end{array}$

\title{
Penyuluhan Manfaat Belimbing Wuluh (Averrhoa bilimbi Linn.) sebagai Tanaman Kesehatan di Kelurahan Kebun Bunga, Kecamatan Sukarami, Palembang
}

\section{Counseling about the Benefits of Averrhoa bilimbi Linn. as a Health Plant in Kebun Bunga Sub-district, Sukarami District, Palembang}

\author{
Aseptianova*, Eka Haryati Yuliany \\ Universitas Muhammadiyah Palembang, Jalan A. Yani No. 13 Palembang, Indonesia
}

\begin{tabular}{|c|c|}
\hline Info Artikel & ABSTRAK \\
\hline $\begin{array}{l}\text { Diterima } 15 \text { Agustus } 2019 \\
\text { Ditelaah } 17 \text { Oktober } 2020 \\
\text { Disetujui } 14 \text { Nopember } 2020 \\
\text { Tersedia daring } 31 \text { Desember } \\
2020 \\
\text { *Penulis untuk korespondensi } \\
\text { nasepti@yahoo.co.id }\end{array}$ & $\begin{array}{l}\text { Belimbing wuluh (Averrhoa blimbi Linn.) mengandung senyawa tanin, flavonoid, } \\
\text { alkaloid, saponin, kalium, asam sitrat dan glikosida. Senyawa-senyawa ini dapat } \\
\text { dimanfaatkan untuk menambah imunitas tubuh sebagai upaya menghindarkan diri dari } \\
\text { penyakit. Pengabdian masyarakat ini bertujuan untuk memberi pemahaman pada } \\
\text { masyarakat dalam meningkatkan kesehatan masyarakat secara mandiri. Penduduk dapat } \\
\text { mengetahui manfaat dari belimbing wuluh sebagai tanaman kesehatan. Kegiatan } \\
\text { pengabdian masyarakat ini menggunakan metode partisipatif. Penyuluhan kepada } \\
\text { masyarakat berpengaruh terhadap kemampuan, perilaku dan meningkatkan peran aktif } \\
\text { masyarakat dalam memanfaatkan tanaman belimbing wuluh untuk kesehatan sehingga }\end{array}$ \\
\hline \multicolumn{2}{|l|}{$\begin{array}{l}\text { Kata Kunci: } \\
\text { Partisipatif, } \\
\text { Kesehatan, } \\
\text { Masyarakat }\end{array}$} \\
\hline & ABSTRACT \\
\hline $\begin{array}{l}\text { Keywords: } \\
\text { Participatory, } \\
\text { Health, } \\
\text { Public }\end{array}$ & $\begin{array}{l}\text { Averrhoa blimbi Linn. contains tannins, flavonoids, alkaloids, saponins, potassium, } \\
\text { citric acid, and glycosides. These compounds can be used to increase the body's } \\
\text { immunity to avoid disease. This community service aims to provide understanding to } \\
\text { the community in improving public health independently. Residents can find out the } \\
\text { benefits of Averrhoa blimbi Linn. as a healthy plant. This community service activity } \\
\text { uses a participatory method. Extension to the community affects the ability and behavior } \\
\text { of the community. It increased the community's active role in utilizing the starfruit plant } \\
\text { for health so that it has an impact on improving public health. }\end{array}$ \\
\hline
\end{tabular}

ISSN 2685-0354 (Media Online). Diterbitkan oleh Universitas Prof. Dr. Hazairin, SH. Ini merupakan jurnal bebas akses di bawah lisensi Creative Commons Atribution 4.0 International (https://creativecommons.org/licenses/by/4.0

\section{PENDAHULUAN}

Secara tradisional, penggunaan tumbuhan tertentu sebagai bahan obat telah lama diketahui dan diterapkan oleh manusia. Seiring dengan perkembangan teknologi, penggunaan beberapa tumbuhan obat sebagai penyembuh penyakit terbukti secara klinis. Penggunaannya menjadi trend akhir-akhir ini. Bahkan, pemerintah menganjurkan penggunaannya untuk meningkatkan derajat kesehatan mandiri. Program tanaman obat keluarga (TOGA) merupakan program yang telah dikenal las oleh masyarakat. Salah satu bahan alami yang telah dipakai dalam pengobatan tradisional adalah belimbing wuluh.

Belimbing wuluh (Averrhoa blimbi Linn.) adalah tanaman buah dari Indonesia yang juga terdapat di daratan Malaya. Tanaman ini banyak tumbuh di pekarangan rumah dan termasuk dalam jenis tumbuhan yang mudah 
dibudidayakan. Selain sebagai obat tradisional, belimbing wuluh seringkali dimanfaatkan sebagai penyedap makanan, rempah masak, pengawet, pembuat makanan terasa segar, pembersih noda pakaian, pembersih tubuh yang kotor, pembersih karat pada logam, keramik. Daun belimbing wuluh bisa mengobati sakit perut, reumatik, gondongan, dan penurun panas. Buah belimbing wuluh dapat dimanfaatkan mengobati batuk rejan, jerawat, tekanan darah tinggi, gusi berdarah, sariawan, gigi berlubang, gangguan dan radang fungsi pencernaan (Parikesit, 2011; Soebiyanto, 2008).

Menurut Parikesit (2011), belimbing wuluh mengandung senyawa gula, fenolik, ion kalsium, asam amino, asam sitrat, vitamin dan sianidin 3-o-h-D-glukosida. Selain itu, belimbing wuluh juga mengandung senyawa flavonoid dan triterpenoid yang dapat berperan sebagai anti bakteri. Muchtadi et al. (2013) mengatakan bahwa belimbing wuluh juga mengandung asam-asam organik. Asam organik dapat berpotensi sebagai antibiotik untuk membasmi bakteri Salmonella sp. Dan membuat mikrofloradi sistem pencernaan menjadi stabil (Gauthier, 2002). Asam organik tertinggi pada belimbing wuluh adalah asam sitrat (92,6-133,8 mg/100 g). Menurut Silalahi dan Sauland (2015), penambahan $0,5 \%$ sari buah belimbing pada ransum dapat menambah berat badan.

Penyuluhan merupakan salah satu usaha untuk meningkatkan kesadaran masyarakat dan upaya menjembatani adanya perubahan perilaku dalam memanfaatkan tanaman untuk kesehatan. Penyuluhan yang dilakukan dapat menggunakan model penyuluhan partisipatif. Menurut Aseptianova (2018), model penyuluhan partisipatif dalam kegiatan pengabdian masyarakat perlu dikembangkan agar masyarakat tidak hanya mengerti tapi juga mampu berkembang aktif. Komunikasi partisipatif dapat memotivasi masyarakat untuk berpartisipasi dalam pembuatan keputusan dalam mencapai sesuatu (Hayat \& Sanusi, 2019). Oleh karena itu, masyarakat tidak hanya diberikan pengetahuan tetapi juga pemahaman dalam meningkatkan kemampuan kognitif dan afektif seperti sikap dan kesadarannya. Masyarakat di Kelurahan Kebun Bunga, Kecamatan Sukarami, Kota Palembang merupakan salah satu komunitas masyarakt yang perlu disuluh mengenai pentingnya kesehatan mandiri menggunakan sumberdaya alam. Luas wilayah kelurahan ini adalah $550 \mathrm{Ha}$ dengan jumlah penduduk \pm 34.483 jiwa.

Pengabdian masyarakat ini ditujukan untuk meningkatkan kesadaran dan minat masyarakat dalam memanfaatkan tanaman belimbing wuluh sebagai bahan pengobatan tradisional. Selanjutnya, masyarakat diharapkan melestarikan dan membudidayakan tumbuhan ini agar biaya pengobatan berkurang dan kemampuan ekonomi meningkat.

\section{METODE}

Pengabdian masyarakat dilaksanakan pada bulan Juli 2019 di Kelurahan Kebun Bunga, Kecamatan Sukarami, Kota Palembang. Pengabdian ini dilaksanakan dalam bentuk penyuluhan dan pelatihan kader PKK dan masyarakat Kelurahan Kebun Bunga, Kecamatan Sukarami, Palembang. Model penyuluhan yang digunakan pada kegiatan ini adalah model partisipatif yang melibatkan tokoh-tokoh di masyarakat dari mulai tingkat rukun warga (RW), rukun tetangga (RT), kelompok Pemberdayaan Kesejahteraan Keluarga (PKK) RW dan RT, Dasawisma, dan kader-kader kesehatan dan lingkungan. Peserta terdiri dari kader PKK dan masyarakat Kelurahan Kebun Bunga, Kecamatan Sukarami, Kota Palembang. Metode pengabdian kepada masyarakat yang digunakan mulai dari ceramah, diskusi dan tanya jawab.

Persiapan pelaksanaan pengabdian masyarakat dilakukan dengan mengumpulkan informasi, diskusi dan analisis situasi lokasi pengabdian. Secara ringkas, tim berbagi informasi tentang pemanfaatan tanaman belimbing wuluh kepada tokoh penting untuk selanjutnya menerima kegiatan dilaksanakan.

\section{HASIL DAN PEMBAHASAN}

Partisipasi aktif masyarakat dibutuhkan untuk mengatasi permasalahan kesehatan dengan meningkatkan derajat kesehatan masyarakat secara mandiri dan optimal. Menurut Setiawati et al. (2016), organisasi kesehatan dunia (World Health Organization/WHO) merekomendasikan pemanfaatan obat tradisional sebagai usaha pemeliharaan kesehatan penduduk, yaitu pengobatan dan pencegahan penyakit-penyakit generative seperti kanker.

Tim pengabdi berupaya untuk mensosialisasikan kepada masyarakat mengenai pemanfaatan tumbuhan obat sebagai salah satu sumber daya kesehatan. Pengabdian masyarakat dengan tema pemanfaatan Belimbing wuluh sebagai tanaman kesehatan telah meningkatkan pengetahuan, kesadaran dan sikap masyarakat Kelurahan Kebun Bunga untuk memanfaatkan tanaman belimbing wuluh sebagai tanaman kesehatan.

Beberapa contoh pemanfaatan belimbing wuluh diberikan pada saat penyuluhan termasuk penggunaan dan manfaatnya terhadap suatu jenis penyakit (Gambar 1, Gambar 2, Gambar 3). Ramuan belimbing wuluh untuk penyakit sariawan dibuat dengan menggunakan segenggam bunga belimbing wuluh dan dicampur dengan gula jawa 
secukupnya. Kemudian, kedua bahan tersebut direbus dengan air satu cangkir hingga mengental. Ramuan didinginkan lalu disaring. Ramuan yang sudah dingin digunakan berkumur dan dioleskan pada bagian yang terkena sariawan (Parikesit, 2011). Belimbing wuluh dapat dimanfaatkan sebagai obat sariawan karena mengandung vitamin $\mathrm{C}$ yang tinggi.

Selain sariawan, tanaman belimbing wuluh dapat dimanfaatkan untuk mengobati diabetes, batuk, rematik, sakit gigi, gondongan, tekanan darah tinggi dan gusi berdarah. Pemanfaatan belimbing wuluh sebagai penyembuh alergi dapat dilakukan dengan jalan perebusan bunga belimbing wuluh dengan air dan gula batu. Ramuan diminum sehari 2-3 kali sampai alergi tidak kambuh lagi. Buah belimbing wuluh juga dapat digunakan untuk menyembuhkan batuk kering karena kandungan kalium untuk mengencerkan dahak dan menurunkan panas.

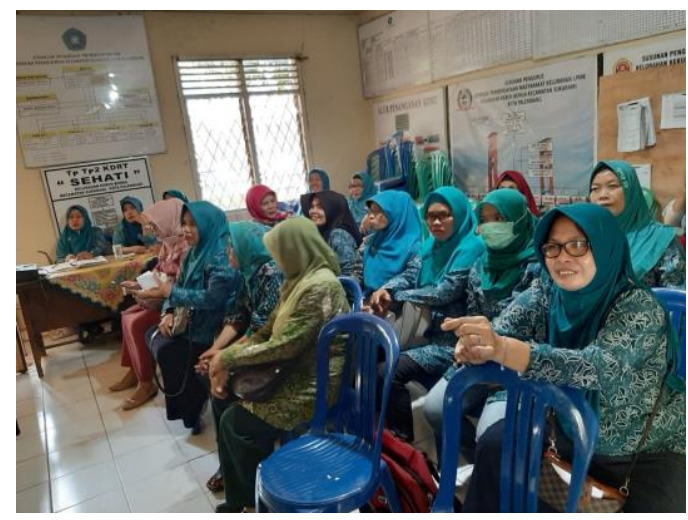

Gambar 1 Peserta kegiatan penyuluhan

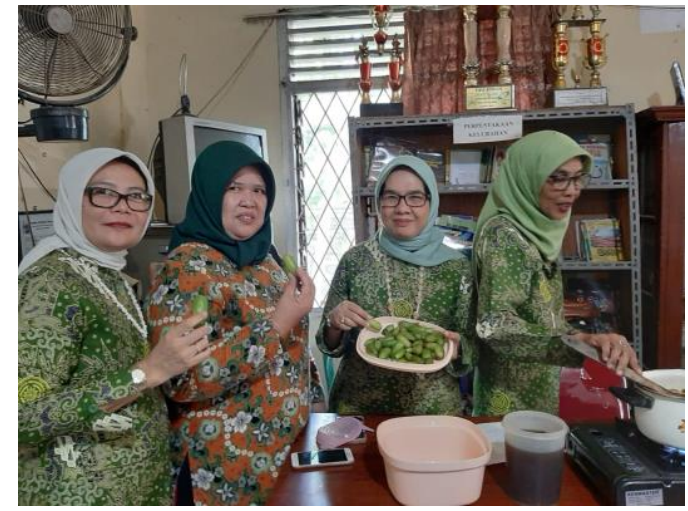

Gambar 2 Praktik dan konsumsi kegiatan dari belimbing wuluh

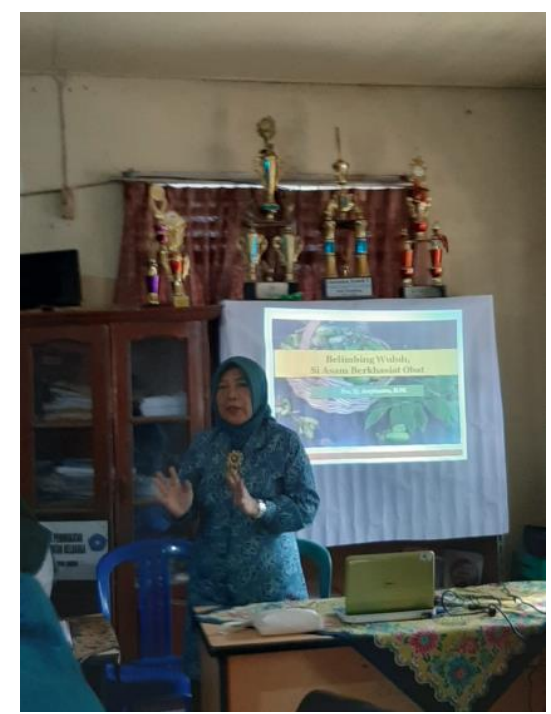

Gambar 3 Nara sumber menyampaikan materi 
Organ buah, daun, batang dan bunga belimbing wuluh mengandung banyak senyawa yang berkhasiat. Buah belimbing wuluh yang sudah matang mempunyai rasa asam dan tinggi kandungan serat yang tinggi. Beberapa kandungan mineral di dalam buah belimbing wuluh adalah kalsium, fosfor, zat besi, dan kalium. Selain itu, di dalam buah belimbing wuluh juga terdapat senyawa kimia yaitu asam format, asam sitrat, asam askorbat (vitamin C), saponin, tanin, flavonoid, glukosid, ribovlavin, vitamin B1, niasin, asam askorbat, karoten, vitamin A (Bhasker \& Shantaram, 2013; Khairunnisa, 2015; Yusbarina \& Marlianis, 2013). Wikanta et al. (2011), perasan belimbing wuluh mengandung senyawa aktif yang berperan sebagai zat antibakteri berupa flavonoid dan triterpenoid. Selanjutnya, Siddique et al. (2013) mengatakan bahwa kulit batang mempunyai kemampuan antimikrobia baik bakteri gram positif maupun bakteri gram negatif seperti bakteri Mycobacterium tuberculosisy yang dapat menyebabkan penyakit batuk kronis pada penderita tuberkolosis (Cheesbrough, 2005).

Pemanfaatan belimbing wuluh sebagai obat tradisional telah digunakan penduduk sejak lama untuk membantu penyembuhan penyakit misalnya jerawat, sariawan, panu, pegal linu, gondongan, rematik, darah tinggi dan sakit gigi. Penggunaan tumbuhan obat tradisional misalnya relatif lebih aman, murah, tidak menimbulkan resistensi, mudah diperoleh dan relatif tidak berbahaya terhadap lingkungan sekitarnya. Selain itu, masyarakat lokal yang memanfaatkan sumber daya tumbuhan akan sangat membantu dalam menjaga kelestarian keanekaragaman hayati dengan usaha domestikasi tanaman obat (Kandari et al., 2010). Dalam penggunaaan obat cina (farmakologi cina), tanaman ini memiliki sifat; rasa asam, sejuk, tanaman ini juga memperbanyak pengeluaran racun dari empedu, anti radang, peluruh kencing, dan astrigen. Bagian tanaman belimbing wuluh dimanfaatkan seperti kulit batang yang memiliki peranan aktivitas antimikroba terhadap bakteri gram positif, fungi maupun gram negatif (Siddique et al., 2013).

Keberhasilan kegiatan pengabdian masyarakat ini ditandai dengan meningkatknya minat masyarakat dalam memanfaatkan belimbing wuluh sebagai obat tradisional. Kegiatan ini meningkatkan partisipasi dan mendorong minat serta komitmen menuju partisipasi yang lebih luas untuk memanfaatkan tanaman belimbing wuluh. Mitra sangat antusias mendengarkan penyuluhan tentang manfaat belimbing wuluh. Selama ini buah belimbing wuluh sangat sedikit sekali pemanfaatannya sehingga banyak yang terbuang. Pada pengabdian masyarakat ini mitra diajarkan tentang pengolahan buah belimbing wuluh sehingga rasa asam yang ada di dalam buah dapat dikendalikan (Gambar 2). Kegiatan dalam pendidikan kesehatan tidak hanya berpengaruh terhadap tingkat kesadaran atau pengetahuan masyarakat tentang kesehatan yang lebih penting adalah mencapai perilaku kesehatan yang baik (Lestari, 2010).

\section{KESIMPULAN}

Pengabdian masyarakat ini telah meningkatkan minat masyarakat untuk memanfaatkan belimbing wuluh sebagai tanaman obat. Hal ini terlihat dari antusiasme para peserta dalam sesi tanya jawab yang dilakukan dan pada akhirnya dapat meningkatkan kesehatan masyarakat. Setelah mengetahui manfaat buah belimbing diharapkan masyarakat juga dapat terus mengonsumsi belimbing wuluh untuk meningkatkan derajat kesehatan secara mandiri.

\section{DAFTAR PUSTAKA}

Aseptianova. (2018). Penyuluhan model partisipatif. Universitas Muhammadiyah Palembang.

Bhasker, B., \& Shantaram, M. (2013). Morphological and biochemical characteristics of Averrhoa fruits Ecology and Distribution of Actinomycetes in Nature-A Review View project Diversity, Distribution, Ecology and Bioprospecting of Micro-and Macro-fungi View project Manjula Shantaram Mangalore university. International Journal of Pharmaceutical, Chemical and Biological Sciences, 3(3), 924-928.

Cheesbrough, M. (2005). District laboratory practice in tropical countries. Cambridge University Press.

Gauthier, R. (2002). Intestinal health, the key to productivity (The case of organic acids). XXVII Convencion ANECAWPDC, 1-14.

Hayat, M. A., \& Sanusi, S. (2019). Pengembangan Desa Lok Baintan dengan pemanfaatan sampah Ilung menjadi kertas. Abdihaz: Jurnal Ilmiah Pengabdian pada Masyarakat, 1(1), 15-21. https://doi.org/10.32663/abdihaz.v1i1.759

Kandari, L. S., Maikhuri, R. K., Rao, K. S., \& Payal, K. (2010). Ethnobotanical study towards conservation of medicinal and aromatic plants in upper catchments of Dhauli Ganga in the Central Himalaya. Journal of Mountain Science, 9(2), 286-296.

Khairunnisa, E. N. (2015). Efek infusa belimbing wuluh (Averrhoa bilimbi) dalam menurunkan kadar glukosa darah puasa dan 2 jam post prandial mencit model diabet [Skripsi]. Fakultas Kedokteran (UNISBA). 
Lestari, D. (2010). Pengaruh pendidikan kesehatan terhadap pengetahuan sikap dan perilaku psk dalam rangka pencegahan ims di lokalisasi Gajah Kumpul Kabupaten Pati [Tesis]. UNS (Sebelas Maret University).

Muchtadi, T. R., Sugiyono, \& Ayustaningwarno, F. (2013). Ilmu pengetahuan bahan pangan. Alfabeta.

Parikesit, M. (2011). Khasiat dan manfaat belimbing wuluh : obat herbal sepanjang zaman. Stomata.

Setiawati, A., Immanuel, H., \& Utami, M. T. (2016). The inhibition of Typhonium flagelliforme Lodd. Blume leaf extract on COX-2 expression of WiDr colon cancer cells. Asian Pacific Journal of Tropical Biomedicine, 6(3), 251-255. https://doi.org/10.1016/j.apjtb.2015.12.012

Siddique, K. I., Uddin, M. M. nasir, Islam, M. S., Parvin, S., \& Shahriar, M. (2013). Phytochemical screenings, thrombolytic activity and antimicrobial properties of the bark extracts of Averrhoa bilimbi. Journal of Applied Pharmaceutical Science, 3(03), 96. https://doi.org/10.7324/JAPS.2013.30318

Silalahi, M., \& Sauland, S. (2015). Pengaruh penambahan sari buah belimbing wuluh (Averrhoa bilimbi) sebagai acidifier terhadap efisiensi ransum pada babi starter. Prosiding Seminar Nasional Sains dan Inovasi Pertanian, $1-30$.

Soebiyanto. (2008). Manfaat tanaman keras Indonesia. Karya Mandiri Nusantara.

Wikanta, W., Abdurrajak, Y., Sumarno, \& Amin, M. (2011). Pengaruh penambahan belimbing wuluh (Averrhoa bilimbi L.) dan perebusan terhadap kadar residu formalin dan profil protein udang putih (Letapenaeus vannamei) berformalin serta pemanfaatannya sebagai sumber pendidikan gizi dan keamanan pangan pada masy. Prosiding Seminar Nasional VIII Biologi, 76-84.

Yusbarina, \& Marlianis. (2013). Penurunan kadar limbah logam timbal (Pb) dengan metode khelasi menggunakan belimbing wuluh. Photon: Jurnal Sain dan Kesehatan, 4(1), 1-8. https://doi.org/10.37859/jp.v4i1.163 